Why do we subsidize donations to the opera?

\author{
Michael Rushton \\ School of Public and Environmental Affairs, Indiana University \\ 1315 East $10^{\text {th }}$ Street, Bloomington, Indiana 47405-1701 USA \\ 812-855-2947 \\ mirushto@indiana.edu
}




\title{
Why do we subsidize donations to the opera?
}

\author{
ABSTRACT \\ In many countries - the United States, Canada, and the United Kingdom, for example - donors \\ to charities receive the identical subsidy through the tax system whether their donation is to a \\ homeless shelter, or to the opera. The way in which charitable giving is subsidized differs across \\ systems, but the equal treatment of very different charities is common to them. Given the \\ different circumstances of the beneficiaries of these various of charities, how can the identical \\ tax subsidy for donations be justified? One approach is to consider the charitable subsidy in light \\ of egalitarian theories of justice, and to ask whether a subsidy to charitable gifts to arts \\ institutions that primary benefit the well-off could be justified within the theory. An alternative \\ approach avoids the overarching theory of just distribution, and focuses instead on the essentially \\ political and practical aspects of the income tax. This essay considers both approaches, \\ concluding that the latter is more appropriate to the question of the charitable subsidy, and that \\ there is a case to be made for equal treatment of donation to charities with markedly different \\ beneficiaries.
}

KEYWORDS: Cultural policy; tax policy; charitable donations

ACKNOWLEDGEMENT: The author is very grateful to the Editor and to anonymous referees for suggestions on an earlier version of this paper. 


\section{Why do we subsidize donations to the opera?}

\section{Introduction}

In recent years there has been a movement to encourage charitable individuals to think carefully about donating to where their contribution would do the most good (Singer, 2013; Pummer, 2016), a practice known as effective altruism. Although effective altruism is subject to the challenge that determining the optimal allocation of philanthropic funds is not that simple - does it necessarily mean aiding the very worst off? Does it burden charities with the duty to provide quantitative estimates of cost-effectiveness, and bias recommendations towards the outcomes most easily quantified? (Gabriel, 2016) - it does provide a challenge to charitable giving to the elite arts, whose beneficiaries are primarily (though not exclusively) the well off.

But regardless of whether the personal arguments for or against donating scarce funds to the arts are persuasive, when it comes to public policy regarding charitable giving there is this fact: in general, the state, through the personal income tax, applies identical treatment to donations that feed the hungry as it does to donations to the opera. A resident of New York City receives the same income tax deduction for a gift to the Community Kitchen of West Harlem as for a gift to the Metropolitan Opera; in Toronto the tax credit is the same for giving to the Good Shepherd Refuge or the Canadian Opera Company; and in Edinburgh, whether giving through payroll deduction or through Gift Aid, it does not matter whether the donation is to the City Mission or the Edinburgh Grand Opera.

In a recent chapter on the treatment of charitable donations in the income tax, examined through the lens of theories of distributive justice, Miranda Perry Fleischer (2017) asks 'how is the opera like a soup kitchen?' It is an important question in considering the ways that charitable 
donations are subsidized by the state. This essay asks the same question, although, as will be shown, with a different approach and a different conclusion.

In the next section of the paper I review the policies, and economic considerations, of the subsidy of personal charitable donations, with special focus on the UK, the US, and Canada. That is followed by an analysis of how distributional considerations ought to, if at all, play a role in the design of the charitable subsidy.

\section{Charitable Giving and the Personal Income Tax}

\section{a. Why is there a special provision for charitable giving at all?}

Special provisions in the personal income tax exist for reasons of efficiency and equity. The efficiency rationale arises from the state wanting to encourage particular kinds of decisions based on their positive external effects. An example would be a tax credit or deduction encouraging investments in green technologies in the home, which serve to benefit not only the homeowner but also the wider community (indeed, the entire planet) as well. The equity rationale arises from an effort to tax individuals equally when they are in equal situations (the principle of horizontal equity), which requires adjustments to gross personal income to reach a fair determination of disposable income that can appropriately serve as the tax base. So, for example, tax systems allow deductions for expenses directly related to earning income, deductions and credits for the care of dependents, and for exceptional medical expenses.

Special provisions in the personal income tax for charitable giving could conceivably be for efficiency or for equity reasons (and these are not mutually exclusive). On efficiency grounds, there is a public benefit to having a healthy nonprofit sector, able to deliver goods and services with public benefit in situations where the state would be less effective than nonprofits, 
say because nonprofits have specific local knowledge and connections that enable them to provide benefits best tailored to local conditions. For example, Rushton (2003) suggests that as cultural tastes become more diverse across the population, nonprofits are better situated than the state to present cultural offerings. As for equity, there is the claim, albeit contested, that charitable gifts should be subtracted from the individual tax base since the donor is not the beneficiary of the gift; it is a general rule that a charitable donation is defined by the fact that it does not engender a personal benefit to the donor in return.

\section{b. What is a charity?}

In the UK, registering as a charity involves stating the purpose of the charity, submitting its governing documents, and being able to show that it falls under one of the designated categories of charity (which includes, among others, "the advancement of the arts, culture, heritage or science") and that it provides a "public benefit". Once registered, it can then apply to HM Revenue and Customs to be eligible for Gift Aid. A public benefit is one that is available to at least a segment of the general public, and the charity cannot be run as what is essentially a private, exclusive club (Morris, 2015; Sanders, 2007). Where disputes have arisen, they have generally fallen under two categories: are any fees charged such that they exclude the public on the basis of income; and is the segment of the population that would potentially benefit so narrowly defined as to not really be "public" in a meaningful sense. So, for example, a school that charges fees must have bursaries available for students from lower-income households, and these must be more than simply token gestures. Since the Charities Act of 2006, it is also necessary for a charity to be able to demonstrate (rather than simply have presumed) an actual "benefit", i.e. that it will "do good" (Sanders, 2007). 
In the US, charities are commonly denoted by the paragraph of the Income Tax Act where they are designated, and the relevant paragraph here is 501(c)(3):

Corporations, and any community chest, fund, or foundation, organized and operated exclusively for religious, charitable, scientific, testing for public safety, literary, or educational purposes, or to foster national or international amateur sports competition (but only if no part of its activities involve the provision of athletic facilities or equipment), or for the prevention of cruelty to children or animals, no part of the net earnings of which inures to the benefit of any private shareholder or individual, no substantial part of the activities of which is carrying on propaganda, or otherwise attempting, to influence legislation (except as otherwise provided in subsection (h)), and which does not participate in, or intervene in (including the publishing or distributing of statements), any political campaign on behalf of (or in opposition to) any candidate for public office.

Nonprofit organizations incorporate in the states in which they are based (and it is state government Attorneys General that have the task of regulating charities), but apply for the tax benefits that come from being a charity through the Internal Revenue Service (IRS), a federal government agency. In practice this is available to apply to all arts organizations that follow the practice of neither having been formed, nor being operated, for private benefit or profit.

In Canada, a charity that intends to operate within a single province incorporates in that province, though if they intend to operate on a national scale they must register through Corporations Canada, a federal government agency (in general, see Duff, 2004). As in the UK and the US, registering for the tax provisions that apply to charities is a separate process, done 
through the Canada Revenue Agency (again, a federal government body). The Government of Canada defines charities as follows:

Registered charities are charitable organizations, public foundations, or private foundations that are created and resident in Canada. They must use their resources for charitable activities and have charitable purposes that fall into one or more of the following categories:

- the relief of poverty

- the advancement of education

- the advancement of religion

- other purposes that benefit the community

In all three countries we see a general pattern: to be eligible for tax relief, the charity must be engaged in an activity with public benefit, which includes a range of activities from the relief of poverty to the presentation of art and culture.

\section{c. The tax treatment of charitable giving in the US, the UK, and Canada}

In the United States, taxpayers can claim a deduction in their personal income tax for donations made to charities registered as 501(c)(3) nonprofit organizations. A consequence of subsidizing charities through an income tax deduction is that the effective rate of subsidy depends on the individual donor's "marginal tax rate," defined as the tax rate that would apply to any additional income earned, or any additional deduction claimed. Like most countries, the U.S. has a progressive income tax rate structure, such that marginal tax rates increase with the individual's taxable income, and as such the marginal tax rate for any person is higher than their "average tax rate," namely their total income tax obligation divided by their total taxable income. 
It is important to note that the deduction for charitable giving in the US Personal Income Tax applies only to those tax filers who take the trouble to "itemize" (i.e., provide a detailed account of) their expenditures that are eligible for tax deduction. Tax filers also have the option of simply claiming the "standard deduction" in lieu of an itemized list (which would also include educational expenses, medical expenses above a particular threshold, a deduction for interest paid on a mortgage on one's principal residence, and others). Only about 30 percent of US tax filers itemize their deductions (Simon, Dale, and Chisholm, 2006), and these are typically higher-income individuals or couples who have more incentives to itemize as a result of their higher marginal tax rates, and because they tend to have larger items that qualify for deduction (higher amounts of charitable giving, or a higher mortgage, for example). The tax reform drafted by Congress and signed into law by President Trump in late 2017 (United States, 2017), doubles the standard deduction, and also limits some of the deductions that can be claimed (the deduction for state and local taxes paid has been removed in the new legislation), which is expected to sharply decrease the number of itemizers, perhaps to as low as 5 percent (Frankel, 2017; note this should be taken as preliminary, since as yet there is not a deep literature of analysis of the new framework, which was devised and became law with great haste).

The method of subsidizing donations in the United Kingdom is similar to that in the U.S. If a U.K. donor arranges her gift through Payroll Giving, the funds are transferred from the employer to the charity prior to tax being deducted from the donor's income. This means that lower rate taxpayers receive a lower subsidy for their donations than those who pay a higher marginal rate of income tax. If the donation is made through the program known as Gift Aid, the donor makes a gift to the charity, and the charity then notifies the government and makes a claim for an additional transfer from the government (equal to $25 \mathrm{p}$ for every $£ 1$ donation). That said, 
Gift Aid is only received when the donor is in fact a taxpayer (and the amount of donation does not exceed four times what the donor paid in tax that year). Further, if the donor is someone with a higher marginal income tax rate, they can make a claim for a credit on their income tax return equal to the difference between the 25 percent Gift Aid subsidy the charity received and the taxpayer's tax rate. The "matching grant" aspect of Gift Aid is necessary because many U.K. taxpayers do not need to file an income tax statement, as the tax collected off their regular payroll at work is deemed sufficient.

So, the U.S. and the U.K. have different means of treating charitable donations, but they have in common the tying of the rate of subsidy to the marginal tax rates applicable to the individual donor. Without giving a catalogue of the income tax treatment of charitable donations across all countries, we can say that most European countries subsidize donations to some extent through a system of deductability from the income tax base, as we have in the U.S. and the U.K., though rules vary in terms of the total amount of deduction that may be claimed in any given year (see Jochum (2015) for a survey).

An alternative method for subsidizing charitable donations is to make the amount of subsidy independent of the donor's marginal tax rate. This can be achieved through the use of an income tax credit. In this case, the amount of the donation is not subtracted from the gross income of the individual in the determination of the tax base. Instead, the donor calculates their tax liability based on total income, and then claims a credit on tax owing, equal to a percentage of eligible donations made that year. The rate of the credit is the same for all taxpayers regardless of marginal income tax rate. A "nonrefundable" tax credit means that the credit may be used to reduce the annual income tax liability to zero, but cannot be used to make the liability negative, such that the government would actually owe a payment to the individual. This is the system 
used in Greece (at a rate of 20 percent (Jochum (2015)), New Zealand (at a rate of 33 1/3 percent), and Canada (where the rate for federal income tax is 15 percent on the first $\$ 200$ of donations and 29 percent on all donations in addition to the first $\$ 200$, and there are additional credits through provincial income taxes that make the effective subsidy even higher).

\section{d. Tax deductions versus tax credits}

There are two major differences between the tax deduction and tax credit methods for the state subsidy of charitable donations. First, the tax credit method decouples the rate of subsidy from the donor's marginal tax rate, or indeed from any tax rate; the tax credit rate can be set at one of the various marginal tax rates in the income tax schedule, or be an entirely different figure. (Note that if the tax credit rate happens by chance to be identical to a donor's marginal tax rate, then the subsidy for that donor is the same under a tax credit or tax deduction framework). In numerical simulations for the U.S. economy, Saez (2004) finds that tying the effective subsidy of charitable donations to the income tax rate leads to more generous subsidies than is optimal. Second, the tax credit method provides for an equal rate of subsidy across all donors, while with the tax deduction method donors with a higher marginal tax rate - essentially the richer donors - receive a higher effective rate of subsidy.

Which method is superior? On this it is instructive to look to the debate in Canada, which switched from the tax deduction method to the tax credit method in 1988. As part of a comprehensive reform of its tax system, Canada (1987) proposed moving a number of personal income tax deductions, including basic personal exemptions, deductions for being disabled, deductions for dependents, deductions for education and medical expenses, and for charitable donations, to tax credits. While the education and medical expenses were to be given tax credits 
in the federal income tax of 17 percent, which was the lower band of marginal tax rate, the tax credit for charitable donations was set at 29 percent, which was then the top marginal income tax rate in the federal system. In practice, this meant that all taxpayers would receive a subsidy for charitable donations at a rate that was previously only gained by those rich enough to be in the highest tax bracket. The rationale was two-fold: to equalize the subsidy across all taxpayers; and to maintain a generous rate of subsidy. Some income tax deductions remain deductions, namely those which apply to expenses necessary to earning income; this ensures that the income tax applies to net rather than gross income. If the goal is to subsidize charitable giving because the government wants to encourage it, as something that serves the public good beyond the benefits felt by the individual donor, then a tax credit would seem to make sense: why have differential rates of subsidy according to the tax bracket of the donor (there might be an exception to this rule if we thought that richer donors responded more at the margin to stronger tax incentives (Cloutier and Fortin, 1989)).

If the goal is to arrive at an appropriate and equitable definition of an income tax base for individuals, and personal funds donated to charity are deemed not to be of benefit to the donor, and thus should not be included in the tax base for personal income, then a deduction is the appropriate method for dealing with donations in the income tax (a case made by Andrews (1972) and by Bittker (1972)). But if the goal is for the state to provide a tax incentive for an activity - charity - that would otherwise be less-than optimally provided, there is a strong case for the tax credit method, which allows the rate of subsidy to be set independently of marginal tax rates, and solves the "upside-down problem" (so-called by Clotfelter (2016) and Hemels (2017)) of richer donors receiving a larger subsidy per amount donated (see Batchelder, 
Goldberg and Orszag (2006) who advocate that the U.S. switch to a tax credit subsidy on these grounds).

\section{The Opera, and other Expensive Tastes}

It might be that neither the argument from the definition of taxable income, nor the subsidy of the nonprofit sector, is a valid reason for any sort of charitable subsidy at all; Brooks (2001) argues that the charitable subsidy gives rich donors the ability to effectively determine the allocation of a tax expenditure, without accountability or transparency, with the allocation biased towards their own concerns and locales; if arts council funders have a program to partially match private donations, then donors' allocative powers over public funds is further amplified. Although Cowen (2006) refers to the charitable subsidy as the "genius" of the U.S. system of subsidizing the arts, Brooks argues that direct grants through arm's length arts councils at least have the virtues of democratic accountability and equity.

But for the purposes of this paper let's assume general agreement that at least some subsidy of charitable giving, in particular when it clearly benefits the impoverished, is accepted as fair. The question before us is whether, if we accept that, there is at the same time a reason for subsidizing, at exactly the same rate, the arts. There are two ways of approaching the question.

\section{a. Philosophical foundations}

One way is to begin by establishing a comprehensive theory of what would constitute fairness or justice in the redistribution (if any) of income, wealth, or other resources, and then to ask how a tax and transfer system would best meet that theory of fairness. This is the approach taken by, for example, McCaffery (1994) and Alstott (2007) with respect to the estate tax (in the 
U.S., the tax that applies at death to individuals with a net estate value, after charitable bequests have been subtracted, that exceed a specific threshold). In a series of papers, Fleischer applies this approach to the personal income tax subsidy to charitable donations, considering how the subsidy is consistent with utilitarian (Fleischer, 2014), libertarian (Fleischer, 2015), and liberal equality (Fleischer, 2011) theories of justice. On utilitarian grounds, Fleischer finds that only a subsidy to charitable donations that benefit the demonstrably poor would be justified, since that represents the only transfer that, on the common assumption of diminishing marginal returns to income, would likely lead to an increase in the sum of all utilities across the population. On those grounds, donations to the opera company would not receive the same tax preferences as donations to the soup kitchen. For limited-government libertarians, although a healthy nonprofit sector provides a valuable alternative means of providing social goods than a coercive state, and from that perspective donations to both the soup kitchen and the opera are to be welcomed, there is an aversion to tax subsidy of charitable donations in that it forces citizens with no interest in some charities from indirectly subsidizing them through having to finance the tax expenditure entailed by the charitable subsidy.

Where Fleischer does find a possibility for a charitable subsidy that would also include arts organizations that in practice primarily serve the well-off, is in what we could summarize as liberal theories of equality. The contemporary starting point for this line of enquiry would be Rawls (1971), who imagined that from behind of "veil of ignorance" regarding what would be our own personal circumstances and abilities, we would agree through a social contract to a social organization that permitted inequalities only to the extent that they worked to the benefit of the worst off, and that would entail the greatest personal liberties, especially in terms of the right to define for oneself what constitutes a good life, consistent with all people enjoying equal 
personal liberties. If we begin from that starting point, the question arises: equality of what? Dworkin (2000) presents a case claiming that equality of resources is a superior goal to equality of welfare, which is related to Rawls (1982) who defines equality in terms of initial allocations of "primary goods". Arneson (1989) suggests equality of "opportunity for welfare", Cohen (2011) for equality of "access to advantage", and Sen (1982) for equality of "capabilities", the variety of goods and rights that enable us to enjoy the range of factors that contribute to a good life. This is a rich literature on which we can barely scratch the surface here, but there is an aspect that warrants focus, since it is at the core of Fleischer's argument: the problem of "expensive tastes".

Suppose we are concerned with equality, and there are some people whose preferences in some realms are such that only access to a good that turns out to be relatively expensive can satisfy those preferences. "Opera" is often used as an example: what does it mean to obtain equality between individuals where some are given the highest pleasures through inexpensive folk music, while for others only live performances of opera, which can only be provided at high cost per audience member, would give the same level of aesthetic satisfaction? Does equality demand that arrangements are made so that our opera-lover and folk-lover are given the same opportunities to enjoy their favourite music? Does it matter if the love of opera was deliberately cultivated by the individual - a "rational addiction" (Becker and Murphy, 1988; Kaplow, 2006) or if it was a part of their childhood upbringing, not actually chosen by the person, and not reversible? And does it make a difference if the expensive taste is held by a relatively poor segment of the population, perhaps an immigrant community for whom traditional music from their homeland plays a very important part of their welfare, though because it is such a minority 
taste in the wider society can be found locally only at great expense? In general the above-cited scholars oppose special compensation for those who have deliberately cultivated expensive tastes; Dworkin uses the deliberately cultivated expensive taste problem as a reason to reject equality of welfare, in favour of equality of resources, as the equalisandum, and Arneson (1989), who is drawn to equality of welfare as the meaningful metric, amends the goal to equality of opportunity for welfare specifically to avoid having to compensate those who have chosen to develop preferences that can only be satisfied by champagne and caviar. Cohen (2011) endorses public funding of community arts centres for those whose nature is to gain satisfaction from arts participation, but while there's nothing morally wrong about cultivating more expensive specific tastes, the rest of the population has no moral obligation to subsidize them. In liberal philosophy, it is a matter of personal responsibility:

"[A]s moral persons citizens have some part in forming and cultivating their final ends and preferences.... it is public knowledge that the principles of justice view citizens as responsible for their ends. In any particular situation, then, those with less expensive tastes have presumably adjusted their likes and dislikes over the course of their lives to the income and wealth they could reasonably expect; and it is regarded as unfair that they now should have less in order to spare others from the consequences of their lack of foresight or self-discipline. (Rawls, 1982, pp. 168-169).

Fleischer (2017) gathers these theories of equality with the term "basic resource egalitarianism" (p. 273), with the starting point that programs designed to provide children with more equal chances of success and developing their talents, through education, and nutrition and health programs, are easily justified within this philosophical framework and uncontroversial. As 
the state directly finances such programs, then where they are delivered through charities (as they often are) a subsidy to such donations falls within the framework of the egalitarian theory of justice. She adds:

(Perhaps) less obvious examples are groups that help poor children develop skills that at first might seem frivolous because they don't directly teach academic or job skills. This would include groups that teach things like music, dance, sports or chess to poor children. Since such groups develop skills like patience, discipline, and teamwork, it seems likely that resource egalitarianism would suggest subsidizing them. Going a step further, basic resource egalitarianism would also suggest subsidizing opportunities for poor children to enjoy cultural programmes like museums, theatres, and dance performances.

This is obviously a much smaller group of activities than those subsidized under current law. Activities like youth recreation programmes and 'elite' cultural activities like the opera and art museums would be subsidized only if they offered free or discounted admission to poor children (or other programmes that help them develop their abilities). (Fleischer, 2017, pp. 273-274).

So, if the opera's outreach to poor children is only but a very small part of its activities, where the much larger part is productions for adults who are generally well-off, then what hope for a subsidy to donations to the opera? If being born with a taste for opera is arbitrary, then individuals with such a taste are faced with a high price for satisfying it. "The operagoer has the bad luck of having expensive tastes, ... The very existence of opera, therefore, furthers resource egalitarianism by making it possible for these individuals to lead their conception of the good 
life" (Fleischer, 2017, p. 276). Fleischer (2011, p. 631) recognizes that it is hard to conceive of how such tastes are innate rather than chosen, and it is at least possible to speculate that there could be instances of individuals who have chosen to cultivate the expensive tastes precisely because they are expensive, being part of an elite "lifestyle" to which they aspire. In the end, "expensive tastes" is a very slender reed on which to place the burden of justifying extending the charitable subsidy to the opera.

\section{b. Tax policy is political}

An alternative approach to the one adopted by Fleischer is to step back from trying to articulate a philosophical foundation of distributive justice from which a tax system can be derived, and to begin instead from the inescapable complexity of tax policy, and the essentially political nature of taxes.

First, as a general rule it is a mistake to go from the general principle that some redistribution in favor of the poor is a good thing for the state to try to achieve, to the claim that every aspect of the tax, transfer, and government spending whole must on its own satisfy the criterion of progressive redistribution. For example, it might be the case that a generous welfare state, with extensive provision of public goods that contribute to greater equality of welfare and opportunity, funded by a relative efficient, though not very progressive, value-added tax, is superior on redistributive grounds to an alternative system relying on a less efficient, though more progressive, personal income tax, and relatively scant provision of public goods. Subsidies to charity ought to be treated as part of a larger framework of taxation and provision of public goods, not just as an isolated feature, and the way to evaluate the fairness of the result is to consider the system and its outcomes in their entirety, and not in a piece-meal fashion. 
Second, suppose we agreed on a framework of evaluation. Economists generally work with a "welfarist" frame, which is not strictly utilitarian (in the sense where maximizing the sum of utilities is the goal), but is more general in the sense that it takes the welfare of individuals as the only consideration in evaluating policy, where in considering the aggregate outcome, individual utilities are weighted according to how much the social welfare function values equality. The seminal paper in optimal taxation by Mirrlees (1971) gives a sense of how little we can know even under the assumption of very specific parameters on elasticities and the social welfare function, with a single, simple personal income tax, and how tremendously complex the analysis is even under very simplifying assumptions. After all, even the basic principle of taxation on the basis of "ability to pay" is violated when we decide to tax the (observable) incomes of individuals rather than the (unobservable) abilities of those individuals to earn income if they gave it all their effort: "The problem of taxation in an economy such as ours is viewed as a problem of indirect control of imperfectly observable variables" (Stiglitz and Boskin, 1977, p. 295). And even if we adopt as our maximand a somehow weighted sum of individual utilities, there is no analysis to which we can turn on how to properly weight differences in utility (which is itself unobservable).

Third, and related, there is no general agreement on what framework for justice is appropriate for evaluating public policy and income distribution. Fleischer (2017) considers the charitable deduction under different frameworks, but there is not, and will never be, a public consensus on how people think about what constitutes justice.

And so the alternative to trying to evaluate the charitable subsidy under different theories of justice is to recognize the system as one that arises out of political deliberation and compromise between people with different material interests and different moral ways of seeing. 
This approach is not new; it can be found in Henry Simons' (1938) rejection of attempts by early economists to construct an optimal utilitarian personal income tax.

As Kymlicka (1993) notes, we can take morality seriously without relying on a specific moral philosophy. No government could possibly select a comprehensive moral framework; even academics who devote their scholarship to this sole topic have no consensus on how we might achieve unity on an issue over which philosophers have debated for centuries. And even with a framework should one be adopted, how could it be consistently applied over the vast range of government spending programs, regulations, transfers and taxes? Sen (2009) reminds us that grand, transcendental theories of justice will not help us rank the choices that are actually available to us.

And so, under this more modest approach, what can we say about subsidizing gifts to the opera under the same rules as gifts to the food bank?

First, we take note that the state in most countries, including the three that were the focus of the first part of this paper, subsidizes the arts through direct allocations, including arts principally enjoyed by elite audiences. There is not universal assent that this is a good policy, but it has been in place for many decades, and the decision to close national arts funding bodies, while suggested by critics, has not been implemented. In asking why the charitable subsidy treats homeless shelters and museums alike, it is important to keep in mind that in terms of direct allocations the state has revealed it values both as goods worthy of public funds, and even if one adopted the approach that a philosophical foundation of equity and justice were required to evaluate the charitable subsidy, this fact is relevant. Although there are not always clear links between the activities of arts councils and the goals they claim to pursue (King and Blaug, 1976), at the most general level there are efficiency gains in subsidizing the arts if the arts generate 
positive externalities in their consumption and production, increasing the social and economic well-being of the population, even for those not directly involved in making or consuming art, and a case for equity in the availability of arts presentations and participation for those with limited means, or who are geographically isolated. There remain differences in direct public support for soup kitchens and opera companies. The former is for a single purpose: to alleviate hunger among the poorest residents. The direct grants to arts organizations have multiple goals, and are clearly not directed solely, or even primarily, towards the poor. The purposes to which public funds are devoted also differ in the two cases. Funds to the local food bank are devoted to the acquisition of more food to distribute. The goal is to allocate a balanced, nutritious basket of groceries, but not to allocate funds to the most expensive, luxury food items. Public funds for the arts, on the other hand, can be devoted to quality over quantity, as stakeholders may have a preference for using funds to deliver the highest quality performances that are possibly available within a given budget, rather than using any additional funds for a wider distribution of arts presentations. The cost to a food bank of acquiring food is exogenous, determined by market prices for food. The cost to an opera company of a production is endogenous, with more or less elaborate productions possible according to budget (for a model of nonprofit decision-making with variable quality, see Newhouse, 1970).

Second, in practice the key to the charitable subsidy lies in what organizations are to be included, i.e. which can obtain listing by the national state revenue authority such that donations to it will be eligible for subsidy. In general, the list of types of organizations contains those which present some sort of public benefit (in the sense that there is not undue exclusion of potential beneficiaries, and that their activities "do good") and that the organization's mission is not private enrichment, i.e. they must be not for profit. Redistribution of income is not the sole 
reason we have charities; they allow for a richer variety of publicly available goods, especially where only a minority of the public would find it valuable, and allow for experimentation and diversity in how their goods and services are made available. Redistribution towards the poor is one rationale for the existence of nonprofit organizations, and may be especially important given the rising levels of income inequality experienced over the past few decades, but it is not the only one. In the U.S. it has even been ruled that a nonprofit art gallery that seems to operate entirely as if it were a commercial firm can have nonprofit status if it is providing cultural opportunities i.e. a charitable aim - that otherwise would not be available in that region (Goldsboro Art League, 1980).

Third, the practical difficulties in granting different rates of subsidy to donations to different types of nonprofit organization would be enormous. Art museums and presenters of live performing arts, even under incentives to demonstrate to the public and the state the degree to which they engage diverse audiences, would be hard-pressed to demonstrate in a very specific way the proportion of their activities that benefit the poor. "The poor" would also require definition, and that in itself would be a tremendous challenge: would it be based upon income? Would arts presenters then need detailed data on incomes of their audiences? Would the figures be capable of being audited by tax authorities?

Fourth, if the arts were to be excluded from the charitable subsidy, or even given a lesser one, how would other sorts of nonprofits be classed, such as recreation centers, community health clinics, or nature preserves? They also have diverse audiences, not all poor, and provide public benefits. Would someone strictly interested in redistribution maintain that only provision of income and necessities to the poor ought to be subsidized? 


\section{Conclusion}

An equal subsidy of donations to charitable organizations of all types, where the charity is required to operate with a public mission and without consideration of private benefit to its managers, is consistent with valuing charities for the enrichment of the goods and services available to the public beyond what is provided by the commercial and the public sectors, and with thinking that it is justified for the state to encourage giving to such organizations. One could follow Brooks (2001) in arguing that no subsidy is justifiable. But if there is a political consensus to subsidize donations, whether through an income tax deduction, a matching grant as found in the U.K., or a Canadian-style tax credit (for which a strong equity and efficiency case could be made), there is no strong case for varying the level of subsidy according to the particular way we would classify the services or the beneficiaries of the nonprofit.

Such a conclusion does not come easily, if at all, from approaching the charitable subsidy from the point of view of the variety of theories of justice and distribution that engaged many of the great political theorists of our time. It is not the weakness of the theorists' models that is the issue. Rather, it is the category error of trying to fit a theory of justice onto a tax system that requires public, political consensus on the appropriate tax base (which must be something observable), exemptions, unit of taxation, and rate structure; it is an attempt to apply moral philosophy to an exceedingly complex practical (large) set of policy choices (what Oakeshott (1962) criticized as "rationalism in politics").

Although it has long been a topic of concern in the field of arts policy, it has always been the case that arts organizations that receive public funds, and whose donors are able to claim a tax subsidy, primarily, though not exclusively, benefit those with higher levels of formal education and who earn higher incomes. Any theory of justice based on egalitarianism will likely 
be at odds with either form of public subsidy, direct or indirect, to the nonprofit arts, because it is so unlikely to represent on net a transfer of resources from richer to poorer. Fleischer (2017) questions under what moral framework a charitable subsidy to the opera can be justified, but from the viewpoint of egalitarian moral philosophy, it is equally difficult to justify direct grants to the opera, and even, as per effective altruism, non-subsidised donations to the opera. Focusing on the charitable subsidy to the opera on its own misses this much larger, and older, question in arts policy.

\section{References}

Alstott, A.L., 2007. Equal opportunity and inheritance taxation. Harvard Law Review, 121, 469542.

Andrews, W.D., 1972. Personal deductions in an ideal income tax. Harvard Law Review, 86, 309-385.

Arneson, R.J., 1989. Equality and equal opportunity for welfare. Philosophical Studies, 56, 7793.

Batchelder, L.L., Goldberg, F.T., and Orszag, P.R., 2006. Efficiency and tax incentives: the case for refundable tax credits. Stanford Law Review, 59, 23-76.

Becker, G.S., and Murphy, K.M., 1988. A theory of rational addiction. Journal of Political Economy, 96, 675-700.

Bittker, B.I., 1972. Charitable contributions: tax deductions or matching grants? Tax Law Review, 28, 37-63. 
Brooks, N., 2001. The tax credit for charitable contributions: giving credit where none is due. In: J. Phillips, B. Chapman, and D. Stevens, eds. Between State and Market: Essays on Charities Law and Policy in Canada. Montreal \& Kingston: McGill-Queen's University Press, 457-481.

Canada, 1987. White Paper on Tax Reform. Ottawa.

Clotfelter, C.T., 2016. Charitable giving and tax policy in the U.S.. In: G. Fack and C. Landais, eds., Charitable Giving and Tax Policy: A Historical and Comparative Perspective. Oxford: Oxford University Press, 35-60.

Cloutier, A.P. and Fortin, B., 1989. Converting exemptions and deductions into credits: an economic assessment. In: J. Mintz and J. Whalley, eds. The Economic Impacts of Tax Reform. Toronto: Canadian Tax Foundation, 45-73.

Cohen, G.A., 2011. On the Currency of Egalitarian Justice. Princeton: Princeton University Press.

Cowen, T., 2006. Good and Plenty: The Creative Successes of American Arts Funding. Princeton: Princeton University Press.

Duff, D.G., 2004. Tax treatment of charitable donations in Canada: theory, practice, and reform. Osgoode Hall Law Journal, 42(1), 47-97.

Dworkin, R., 2000. Sovereign Virtue. Cambridge, MA: Harvard University Press.

Fleischer, M.P., 2010. Theorizing the charitable tax subsidies: the role of distributive justice. Washington University Law Review, 87, 505-566.

Fleischer, M.P., 2011. Equality of opportunity and the charitable tax subsidies. Boston University Law Review, 91, 601-663. 
Fleischer, M.P., 2014. Charitable giving and utilitarianism: problems and priorities. Indiana Law Journal, 89, 1485-1523.

Fleischer, M.P., 2015. Libertarianism and the charitable tax subsidies. Boston College Law Review, 56, 1345-1415.

Fleischer, M.P., 2017. How is the opera like a soup kitchen? In: M. Bhandari, ed., The Philosophical Foundations of Tax Law. Oxford: Oxford University Press, 255-79.

Frankel, T.C., 2017. Charities fear tax bill could turn philanthropy into a pursuit only for the rich. Washington Post (December 23).

Gabriel, I., 2016. Effective altruism and its critics. Journal of Applied Philosophy, 34(4), 457473.

Goldsboro Art League, Inc., v. Commissioner (1980). 79 T.C. No. 28 (December 8).

Hemels, S., 2017. Tax incentives for museums and cultural heritage. In: S. Hemels and K. Goto, eds., Tax Incentives for the Creative Industries. Singapore: Springer, 107-135.

Jochum, H., 2015. Deduction of gifts and contributions and other tax incentives in the PIT and CIT for non-profit entities or activities. In: Taxation of Charities: 2012 EATLP Congress. Amsterdam: International Bureau of Fiscal Documentation, 61-74.

Kaplow, L., 2006. Choosing expensive tastes. Canadian Journal of Philosophy, 36, 415-425.

King, K., and Blaug, M., 1976. Does the Arts Council know what it is doing? In: M. Blaug, ed., The Economics of the Arts. London: Martin Robinson, 101-125.

Kymlicka, W., 1993. Moral philosophy and public policy: the case of NRT's. Bioethics, 7(1), 126.

McCaffery, E.J., 1994. The political liberal case against the estate tax. Philosophy and Public Affairs, 23(4), 281-312. 
Mirrlees, J.A., 1971. An exploration in the theory of optimal income taxation. Review of Economic Studies, 38, 175-208.

Morgan, G.G., 2012. Public benefit and charitable status: assessing a 20-year process of reforming the primary legal framework for voluntary activity in the UK. Voluntary Sector Review, 3(1), 67-91.

Morris, D., 2015. Elasticity of the boundaries in England and Wales: What is (and isn't) charitable? An opportunity lost (or not yet fully embraced)? Conference Proceedings: Elasticity of the Boundaries: What Is (and Isn't) Charitable? New York University, National Center on Philanthropy and the Law [http://ncpl.law.nyu.edu/wpcontent/uploads/2016/08/Tab-G-Morris-paper.pdf].

Newhouse, J.P., 1970. Toward a theory of nonprofit institutions: an economic model of a hospital. American Economic Review, 60(1), 64-74.

Oakeshott, M., 1962. Rationalism in Politics and other essays. London: Methuen.

Pummer, T., 2016. Whether and where to give. Philosophy and Public Affairs, 44(1), 77-95.

Rawls, J., 1971. A Theory of Justice. Cambridge, MA: Harvard University Press.

Rawls, J. 1982. Social unity and primary goods. In: A. Sen and B. Williams, eds., Utilitarianism and Beyond. Cambridge, UK: Cambridge University Press, 159-185.

Rushton, M. 2003. Cultural diversity and public funding of the arts: a view from cultural economics. Journal of Arts Management, Law, and Society, 33(2), 85-97.

Saez, E., 2004. The optimal treatment of tax expenditures. Journal of Public Economics, 88, 2657-2684.

Sanders, A., 2007. The mystery of public benefit. Charity Law and Practice Review, 10(2), 3357. 
Sen, A., 1982. Equality of what? In: Choice, Welfare and Measurement. Cambridge, MA: MIT Press, 353-369.

Sen, A., 2009. The Idea of Justice. Cambridge, MA: Harvard University Press.

Simon, J., Dale, H., and Chisolm, L., 2006. The federal tax treatment of charitable organizations. In: W.W. Powell and R. Steinberg, eds. The Nonprofit Sector: A Research Handbook $\left(2^{\text {nd }}\right.$ edition). New Haven: Yale University Press, 267-306.

Simons, H.C., 1938. Personal Income Taxation. Chicago: University of Chicago Press.

Singer, P., 2013. Good charity, bad charity. New York Times Sunday Review (August 11), SR4.

Stiglitz, J.E., and Boskin, M.J., 1977. Some lessons from the new public finance. American Economic Review, Papers and Proceedings, 67(1), 295-301.

United States, 2017. "Tax Cuts and Jobs Act", $115^{\text {th }}$ Congress, $1^{\text {st }}$ Session, H.R.1 [https://waysandmeansforms.house.gov/uploadedfiles/bill_text.pdf]. 